\title{
AEROSOL TYPING BASED ON MULTIWAVELENGTH LIDAR OBSERVATIONS AND METEOROLOGICAL MODEL DATA
}

\author{
Maria Mylonaki ${ }^{1 *}$, Elina Giannakaki ${ }^{2,3}$, Alexandros Papayannis ${ }^{1}$, Elena Floca ${ }^{2}$, Mika Komppula ${ }^{3}$ \\ ${ }^{1}$ Laser Remote Sensing Unit, Physics Department, School of Applied Mathematics and Physical Sciences, \\ National Technical University of Athens, 15780 Zografou, Greece \\ ${ }^{2}$ Department of Environmental Physics and Meteorology, Faculty of Physics, National and Kapodistrian \\ University of Athens, 15780 Zografou, Greece \\ ${ }^{3}$ Finnish Meteorological Institute, P.O.Box 1627, 70211 Kuopio, Finland \\ *Email:mylonaki.mari@gmail.com
}

\begin{abstract}
Three different aerosol classification methods have been used to characterize lidar observations: Mahalanobis distance automatic aerosol type classification, Neural Network Aerosol Typing Algorithm (NATALI) and Source and Analysis (SCAN) aerosol classification. The data selection has been made through the EARLINET database depending on the $3 \mathrm{~b}+2 \mathrm{a}+1 \delta$ optical property availability. One hundred aerosol layers from four EARLINET stations (Bucharest, Kuopio, Leipzig and Potenza) have been classified. We present a typical case study of aerosol characterization observed by the MUSA system over Potenza on the $11^{\text {th }}$ of April 2016 (20:30-21:30 UTC).
\end{abstract}

\section{INTRODUCTION}

Aerosol typing is essential for understanding the impact of the different aerosol sources (desserts, wildfires, sea spray, anthropogenic emissions, volcanoes) on various atmospheric research topics such as air quality, meteorology, cloud microphysics and radiative forcing [1].

Lidars have proven to be an appropriate tool in detecting aerosol layers with high spatial and temporal resolution [2,3]. Furthermore, multiwavelength Raman/depolarization lidars can be used on aerosol characterization (ie. dust, smoke, continental, etc.) as they provide verticallyresolved information of extensive (particle backscatter and extinction coefficient, volume depolarization ratio) and intensive (lidar ratio, Ångström exponent, linear particle depolarization ratio) optical properties.

\section{METHODOLOGY}

\subsection{Classification methods}

Automatic aerosol type classification Mahalanobis distance
This method is a lidar stand-alone classification algorithm which uses four (or three) lidar intensive properties (Lidar Ratio (LR), ratio of Lidar Ratio $\left(\mathrm{LR}_{\lambda 1} / \mathrm{LR}_{\lambda 2}\right)$, Ångström Exponent $\left(\mathrm{AE}_{\lambda \alpha} / \lambda_{\beta}\right)$ and Linear Particle Depolarization Ratio (LPDR) (if provided)) in order to classify the measured aerosol data into 8 types: Volcanic (V), Smoke (S), Marine (M), Dust (D), Continental (C), Polluted Dust (PD), Polluted Continental (PC) and Mixed Dust (MD) or C, D, M, MD, PC, PD if LPDR is not provided (Table 1). Basically, this technique assigns any given $\mathrm{N}$-dimensional point $\left(\mathrm{x}_{1}, \mathrm{x}_{2}, \ldots, \mathrm{x}_{\mathrm{N}}\right)$ (observation) to the cluster (created with EARLINET network-wide typing results already published in literature) that has minimum Mahalanobis distance from that point [4].

\section{Neural Network Aerosol Typing Algorithm - NATALI}

NATALI is based on artificial neural networks (ANNs) trained (using data from OPAQ components + relative humidity (RH), GADS microphysics and Mischenko spheroidal model) to estimate the most probable aerosol type from, solely, a set of multispectral lidar data (Color Index (CI), Color Ratio (CR), LR, $\mathrm{AE}_{\lambda \alpha} / \lambda \beta$ and LPDR (if provided)). The 14 aerosol types (high resolution typing) are: Continental, Continental Polluted, Smoke, Dust, Marine, Volcanic, Continental Dust, Marine Mineral, Continental Smoke, Dust Polluted, Coastal, Coastal Polluted, Mixed Dust and Mixed Smoke (Table 1) [5].

\section{Source and Analysis aerosol classification - SCAN}

SCAN aerosol classification uses the backwardtrajectories for certain height levels (ie. from 0.5 $\mathrm{km}$ to $6.0 \mathrm{~km}$ with a step of $250 \mathrm{~m}$ ) created with Hybrid Single-Particle Lagrangian Integrated Trajectory (HYSPLIT) [6] in combination with 
satellite data (e.g fire/hotspot information based on FIRMS/MODIS [7]). Each aerosol layer is associated to one trajectory level regarding the middle height of the layer. To identify the source region of particles SCAN, firstly, assumes certain regions above Earth: West - Northwest, North Northeast, Maritime and Local areas for Europe and long-range transport for the other continents. Then, it calculates the hours that air-mass is above of each region, the mean height in each region as well as the minimum of the height. In order to associate the observed layers to certain aerosol source, it is required that the mean height of each region is lower than $3 \mathrm{~km}$. If the mean height is above $3 \mathrm{~km}$, the minimum height of each region is checked and if it is lower than $2 \mathrm{~km}$ then the certain region is chosen as the source of the observed layer. If these two criteria are not indulged to none of the regions, then the layer is characterized as unknown. If these two criteria are indulged into more than 2 regions a mixture of more than one aerosol types is assumed. The 12 aerosol types of SCAN aerosol classification are: Smoke, Marine, Dust, Continental, Dust Polluted, Marine Mineral, Mixed Dust, Continental Smoke, Coastal and Mixed Smoke. The variable of the height of the air parcel above the source region is also used.

Table 1: Aerosol types according to Mahalanobis, NATALI and SCAN classification algorithms.

\begin{tabular}{|c|c|c|c|c|}
\hline & Aerosol Type & Mahalanobis (with LPDR) & $\begin{array}{c}\text { NATALI (with LPDR, high } \\
\text { resolution) }\end{array}$ & SCAN \\
\hline 1 & Smoke & Smoke (S) & Smoke (S) & Smoke (S) \\
\hline 2 & Marine & Marine (M) & Marine (M) & Marine (M) \\
\hline 3 & Dust & Dust (D) & Dust (D) & Dust (D) \\
\hline 4 & Clean Continental & Clean Continental (CC) & Clean Continental (CC) & Continental (C) \\
\hline 5 & Continental Polluted & Continental Polluted (CP) & Continental Polluted (CP) & Continental (C) \\
\hline 6 & Dust with Smoke/Continental & Dust Polluted (DP) & $\begin{array}{c}\text { Dust Polluted (DP) } \\
\text { Continental Dust (CD) } \\
\end{array}$ & Dust Polluted (DP) \\
\hline 7 & Dust/Volcanic with Marine & Mixed Dust (MD) & Marine Mineral (MM) & Marine Mineral (MM) \\
\hline 8 & Continental with Dust and Marine & Unknown & Mixed Dust (MD) & Mixed Dust (MD) \\
\hline 9 & Continental with Smoke & Unknown & Continental Smoke (CS) & Continental Smoke (CS) \\
\hline 10 & Continental with Marine & Unknown & Coastal (Coas) & Coastal (Coas) \\
\hline 11 & Continental Polluted with Marine & Unknown & Coastal Polluted (CoasP) & Coastal (Coas) \\
\hline 12 & $\begin{array}{c}\text { Continental with Smoke and } \\
\text { Marine }\end{array}$ & Unknown & Mixed Smoke (MS) & Mixed Smoke (MS) \\
\hline 13 & Volcanic & Volcanic (V) & Volcanic (V) & - \\
\hline
\end{tabular}

\subsection{Data and lidar stations}

Data and lidar station selection depended on the availability of the vertical profiles of the full set of aerosol optical properties: backscatter coefficient $\left(b_{355}, b_{532}, b_{1064}\right)$, extinction coefficient $\left(\mathrm{e}_{355}, \mathrm{e}_{532}\right)$, Lidar Ratio $\left(\mathrm{LR}_{355}, \mathrm{LR}_{532}\right)$, Ångström exponent
$\left(\mathrm{AE}_{355} /{ }_{532}, \mathrm{CI}_{355 / 532}, \mathrm{CI}_{532 / 1064}\right)$ and Linear Particle Depolarization Ratio $\left(\mathrm{LPDR}_{532}\right)$ at the EARLINET database (https://www.earlinet.org) within the years 2014-2018. The 4 lidar stations performed the used measurements are: Kuopio, Finland; Bucharest, Romania; Leipzig, Germany; and Potenza, Italy (Table 2).

Table 2: EARLINET lidar station information

\begin{tabular}{|c|c|c|c|c|c|c|}
\hline Location & $\begin{array}{l}\text { ACTRIS } \\
\text { Code }\end{array}$ & Institute & $\begin{array}{l}\text { Coordinates (lat, long, } \\
\text { altitude amsl) }\end{array}$ & Ref. & $\begin{array}{l}\text { No of } \\
\text { cases }\end{array}$ & Year \\
\hline Bucharest & INO & National Institute of R\&D for Optoelectronics (INOE) Link & $44.35 \mathrm{~N}, 26.03 \mathrm{E}, 93 \mathrm{~m}$ & [8] & 7 & 2017 \\
\hline Kuopio & KUO & $\begin{array}{l}\text { Finnish Meteorological Institute (FMI), Atmospheric Research } \\
\text { Centre of Eastern Finland, Kuopio Link }\end{array}$ & $62.74 \mathrm{~N}, 27.54 \mathrm{E}, 190 \mathrm{~m}$ & {$[9,10]$} & 9 & 2015,2016 \\
\hline Leipzig & LEI & Leibniz Institute for Tropospheric Research, Leipzig Link & $51.35 \mathrm{~N}, 12.43 \mathrm{E}, 90 \mathrm{~m}$ & {$[9,10]$} & 17 & 2018 \\
\hline Potenza & POT & $\begin{array}{l}\text { Consiglio Nazionale delle Ricerche - Istituto di Metodologie per } \\
\text { l'Analisi Ambientale (CNR-IMAA), Potenza Link }\end{array}$ & $40.60 \mathrm{~N}, 15.72 \mathrm{E}, 760 \mathrm{~m}$ & [11] & 64 & $2015-2016$ \\
\hline
\end{tabular}




\section{RESULTS}

\subsection{Case study}

In the following we present a typical case study of aerosol characterization. On the $11^{\text {th }}$ of April 2016 (20:30-21:30 UTC) an aerosol layer was observed by the MUSA system over Potenza (Fig. 1a, b).

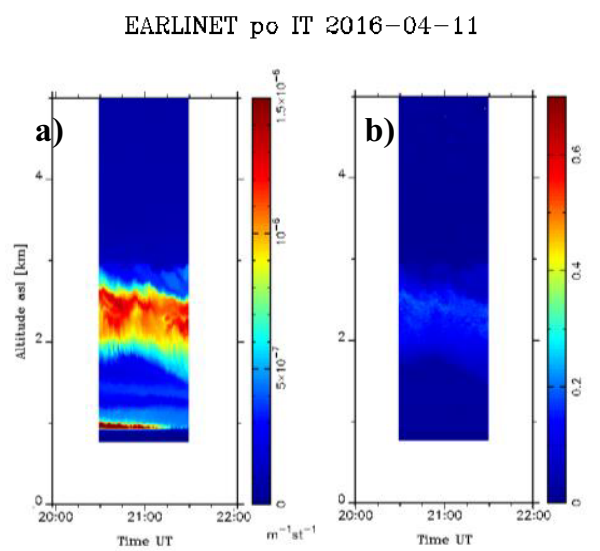

Figure 1: Temporal evolution of the a) $1064 \mathrm{~nm}$ range-corrected lidar signal and b) $532 \mathrm{~nm}$ volume linear depolarization ratio obtained by the MUSA system over Potenza on the $11^{\text {th }}$ of April 2016 (20:3021:30 UTC).

The aerosol layer boundaries were calculated by applying the gradient method on the $1064 \mathrm{~nm}$ backscatter coefficient profile [12] and found 1.9 $\mathrm{km}$ (cf. Fig.2-bottom lower horizontal red line) and $2.7 \mathrm{~km}$ (cf. Fig.2-top upper horizontal red line) above mean sea level (amsl).

Optical profiles of the extensive and intensive aerosol properties were retrieved. The mean values and standard deviation of the properties of the aerosol layer (1.9-2.7 $\mathrm{km}$ amsl) are: LPDR 15 $\pm 4[\%], \mathrm{LR}_{355} 37 \pm 4[\mathrm{sr}], \mathrm{LR}_{532} 49 \pm 5[\mathrm{sr}]$, $\mathrm{AE}_{355 / 532}-0.7 \pm 0.2, \mathrm{CI}_{355 / 532}-0.1 \pm 0.3$ and $\mathrm{CI}_{532 / 1064} 0.3 \pm 0.1$ (Fig. 2).
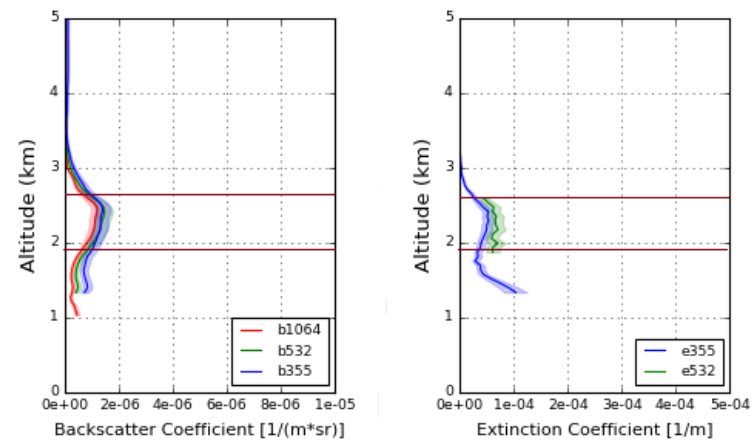

Mahalanobis distance automatic aerosol type classification classified the aerosol layer observed over Potenza on the $11^{\text {th }}$ of April 2016 (20:3021:30 UTC) between 1.9-2.7 km amsl as "Mixed Dust". The maximum weighted probability of the classification was $59.1 \%$ for Mixed Dust, followed by Dust with $20.1 \%$ probability and Clean Continental with $11.1 \%$ probability. Lower values of probability were found for the aerosol types of Smoke, 6.3\%; Polluted Dust, 1.8\%; Marine, $1.3 \%$ and Volcanic, $0.3 \%$ (Fig. 3).

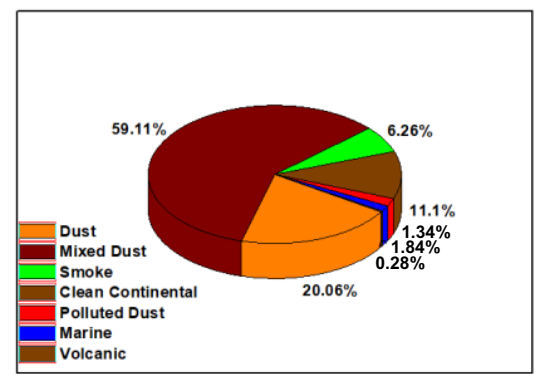

Figure 3: Mahalanobis distance automatic aerosol type weighted probabilities for the case study measured over Potenza on the $11^{\text {th }}$ of April 2016 (20:30-21:30 UTC) between 1.9-2.7 km amsl.

NATALI classified the aerosol layer observed over Potenza on the $11^{\text {th }}$ of April 2016 (20:30 21:30 UTC) between 1.9-2.7 km amsl as "Mixed Dust" with 93\% confidence and 11347 Agreements (Table 3).

Finally, the 96-hour HYSPLIT backward trajectories arriving at $1.5 \mathrm{~km}$ above ground level (agl) (2.2 km amsl) (Fig. 4, red line) and $2.0 \mathrm{~km}$ agl (2.7 km amsl) (Fig. 4, blue line) over Potenza on the $11^{\text {th }}$ of April 2016 (20:30-21:30 UTC) used by SCAN are shown in Figure 4.

Figure 2: Optical profiles measured over Potenza on the $11^{\text {th }}$ of April 2016 (20:30-21:30 UTC). 
Table 3: NATALI classification of the aerosol layer measured over Potenza on the $11^{\text {th }}$ of April 2016 (20:30-21:30 UTC) between 1.9- $2.7 \mathrm{~km}$ amsl.

\begin{tabular}{|c|c|}
\hline Predominant Component & Dust \\
\hline Aerosol Type & Mixed Dust/CC \\
\hline A1H Answer & Mixed Dust/CC \\
\hline A1H Confidence & 0.88 \\
\hline A1H Agreements & 13200 \\
\hline A2H Answer & Unknown \\
\hline A2H Confidence & 0 \\
\hline A2H Agreements & 0 \\
\hline A3H Answer & Mixed Dust/CC \\
\hline A3H Confidence & 0.93 \\
\hline A3H Agreements & 11347 \\
\hline
\end{tabular}

The maximum probability of the first classification was $78.1 \%$ for Marine, followed by $13.4 \%$ for Dust and $9.3 \%$ for Continental. However, the minimum height that the air parcel reached during its 96-hour travel was $2.5 \mathrm{~km}$ amsl, so the marine contribution assumed to be negligible. As a result, SCAN classified the aerosol layer observed over Potenza on the $11^{\text {th }}$ of April 2016 (20:30-21:30 UTC) between 2.0-2.5 km amsl as "Dust Polluted".

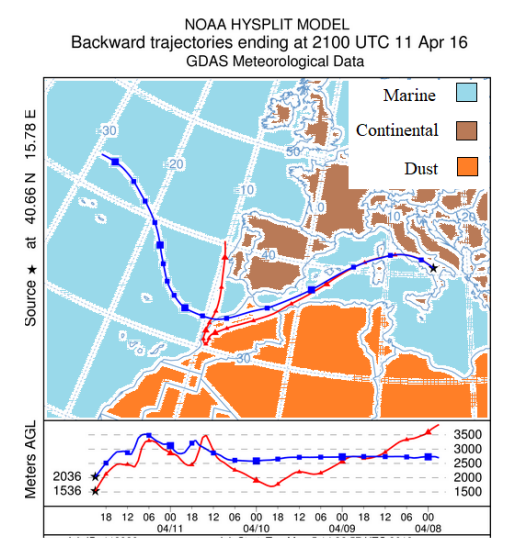

Figure 5: 96-hour HYSPLIT backward trajectories arriving at $1.5 \mathrm{~km}$ a.g.l. (2.2 km amsl) (red line) and $2.0 \mathrm{~km}$ agl $(2.7 \mathrm{~km}$ amsl) (blue line) over Potenza on the $11^{\text {th }}$ of April 2016 (20:30-21:30 UTC).

For the case study of the $11^{\text {th }}$ of April 2016 (20:30-21:30 UTC) the 3 different classification algorithms classified the aerosol layer observed between 1.9 and $2.7 \mathrm{~km}$ as mixture of Dust with Marine and/or Continental.

Future work targets at the investigation of the discrepancies of such cases and the statistical analysis of the comparison of the 3 aerosol layer classification methods.

\section{ACKNOWLEDGEMENTS}

We acknowledge support of this work by the project "PANhellenic infrastructure for Atmospheric Composition and climatE change" (MIS 5021516) which is implemented under the Action "Reinforcement of the Research and Innovation Infrastructure", funded by the Operational Programme "Competitiveness, Entrepreneurship and Innovation" (NSRF 2014-2020) and co-financed by Greece and the European Union (European Regional Development Fund). The financial support for EARLINET by the European Union under grant RICA 025991 in the FP6 is gratefully acknowledged. Part of this research has been co-financed by additional funding from the European Union FP7 (/2007-2013) under grant agreement no 262254.The authors gratefully acknowledge the NOAA Air Resources Laboratory for the provision of the HYSPLIT transport and dispersion model and READY website (http://www.ready.noaa. gov) used in this publication. MODIS-FIRMS data were provided by EARTHDATA (EOSDIS-NASA).

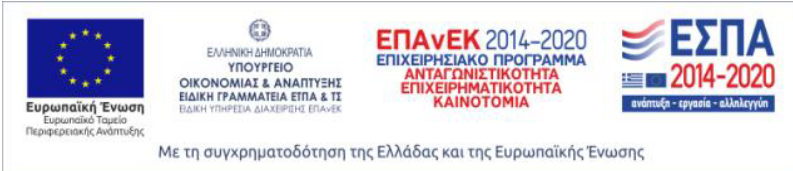

\section{REFERENCES}

[1] IPCC. Cambridge University Press, 571-658 (2014)

[2] E. Giannakaki, et al., Atmos. Chem. Phys., 16, 8109-8123 (2016)

[3] O. Soupiona, et al., Atmos. Environ., 183, 165-174 (2018)

[4] N. Papagiannopoulos, et al., Atmos. Chem. Phys., 18, 15879-15901 (2018)

[5] D. Nicolae, et al., Atmos. Chem. Phys., 18, 1451114537 (2018)

[6] R. R. Draxler, et al., Aust. Meteor. Mag., 47, 295308 (1998)

[7] D. K. Davies, IEEE J-STARS, 47, 72-79 (2009)

[8] A. Nemuc, et al., Atmos. Meas. Tech, 6, 3243-3255 (2013)

[9] D. Althausen, et al., J. Atmos. Oceanic Technol., 26, 2366-2378 (2009)

[10] R. Engelmann, et al., Atmos. Meas. Tech., 9, 1767-1784 (2016)

[11] F. Madonna, et al. Atmos. Meas. Tech., 4, 11911208 (2011)

[12] L. Belegante, et a;., Acta Geophys., 62, 276-289 (2014) 